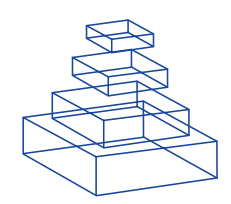

\title{
The critical role of Golgi cells in regulating spatio-temporal integration and plasticity at the cerebellum input stage
}

\author{
Egidio D’Angelo*,+
}

* Department of Cellular and Molecular Physiological and Pharmacological Sciences, University of Pavia and CNISM, Pavia, Italy.

Edited by:

Alexander Borst, Max Planck Institute of Neurobiology, Germany

Reviewed by: Yosef Yarom, Hebrew University, Israel Michael Hausser, University College London, UK

${ }^{\dagger}$ Correspondence:

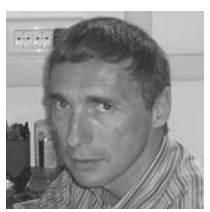

Dr. Egidio D'Angelo is Full Professor of Physiology at the Department of Physiology of the University of Pavia in Italy. After the $M D$, he obtained the specialization in Neurology and did his post-doc in John Garthwaite (UK) and Per Andersen (Norway) groups. His activity is dedicated to investigations on neuronal properties and long-term synaptic plasticity in the cerebellar circuit. Electrophysiological and imaging techniques in vitro and in vivo are complemented by detailed computational models of single neurons and synapses.

dangelo@unipv.it

The discovery of the Golgi cell is bound to the foundation of the Neuron Doctrine. Recently, the excitable mechanisms of this inhibitory interneuron have been investigated with modern experimental and computational techniques raising renewed interest for the implications it might have for cerebellar circuit functions. Golgi cells are pacemakers with preferential response frequency and phase-reset in the theta-frequency band and can therefore impose specific temporal dynamics to granule cell responses. Moreover, through their connectivity, Golgi cells determine the spatio-temporal organization of cerebellar activity. Finally, Golgi cells, by controlling granule cell depolarization and NMDA channel unblock, regulate the induction of long-term synaptic plasticity at the mossy fiber - granule cell synapse. Thus, the Golgi cells can exert an extensive control on spatio-temporal signal organization and information storage in the granular layer playing a critical role for cerebellar computation.

Keywords: Golgi cell, cerebellum, synaptic inhibition, LTP and LTD

\section{NTRODUCTION AND SUMMARY OF CONCEPTS}

After the discovery at the end of the 19th century (Golgi, 1883), the Golgi cell (Figure 1) was precisely described by Cajal $(1987,1995)$ and functionally identified as an inhibitory interneuron 50 years later by Eccles et al. (1967). Then, its role has been casted by Marr (1969) within the Motor Learning Theory as a codon size regulator of granule cell activity. It was immediately clear that Golgi cells had to play a critical role, since they are the main inhibitory interneuron of the granular layer and control activity of as many as 100 billions granule cells. However, with few exceptions, investigation on Golgi cells has lagged until recently, when renewed interest for cerebellar network functions and for cellular physiology in vitro and in vivo has led to discover the intrinsic electroresponsive properties and typical firing patterns of these neurons. In vitro,
Golgi cells show pacemaking, resonance, phase-reset and rebound-excitation in the theta-frequency band. These properties are likely to impact on their activity in vivo, which shows irregular spontaneous beating modulated by sensory inputs and burst responses to punctuate stimulation followed by a silent pause. Moreover, Golgi cell connectivity within the network suggest how these neurons could regulate the spatio-temporal organization of cerebellar activity. It turns out that Golgi cells can control both the temporal dynamics and the spatial distribution of information transmitted through the cerebellar network. Moreover, Golgi cells regulate the induction of longterm synaptic plasticity at the mossy fiber-granule cell synapse. Thus, the concept is emerging that Golgi cells are of critical importance for regulating granular layer network activity bearing important consequences for cerebellar computation as a whole. 


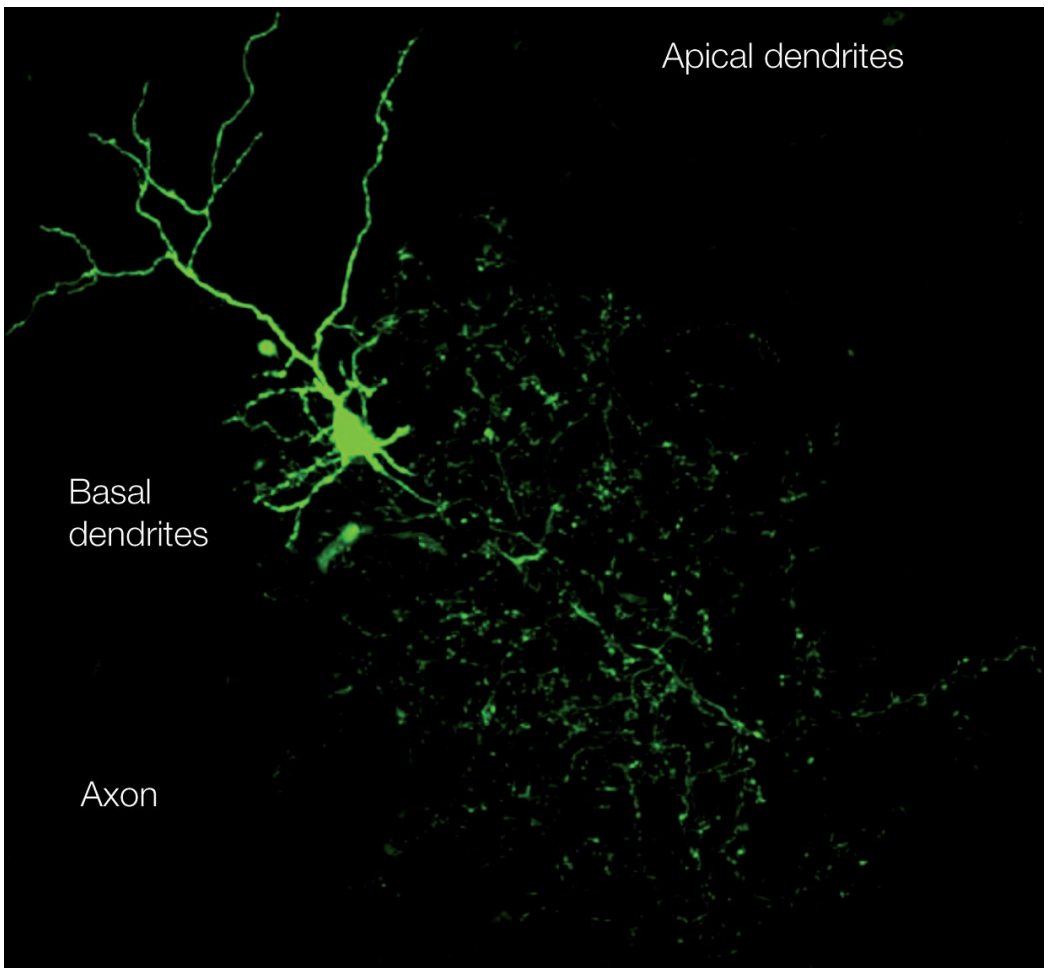

Figure 1 | The Golgi cell. The image of a Golgi cell filled with AlexaFluo through a patch-clamp pipette (removed) in an acute cerebellar slice is reconstructed with a confocal microscope (stack view). It can be noted the broad extension of the axonal plexus, the multiple short basal dendrites and two apical dendrites climbing into the molecular layer (kindly provided by Guillaime Dugué and Stephane Dieudonné).
The Golgi cell is extensively interconnected within the cerebellar network (Figure 2). Palay and Chan-Palay (1974), in their detailed analysis of the cerebellar circuits, showed that the main input to Golgi cells come from the mossy fibers, which form synapses on the basal dendrites presumably in the glomeruli. Granule cells were reported to form their main connection with the Golgi cell through the parallel fibers and also possibly through synapses en passant along the ascending axon. The climbing fibers have been reported to form connections with Golgi cells by extending thin collateral branches just below the Purkinje cells and reentering into the upper part of the granular layer (Shinoda et al., 2000). The Golgi cells also receive inhibitory innervation from stellate/basket cells and Lugaro cells. Although morphological evidence defines the principles of Golgi cell wiring, functional evidence for these connections is still incomplete. It is known that afferent activity readily activates the Golgi cell involving both the mossy fiber and the parallel fiber inputs and there is evidence that molecular layer neurons can inhibit the Golgi cells (Eccles et al., 1967; Vos et al., 1999a). However, while a careful physiological analysis has been performed for the granule cell $\rightarrow$ Golgi cells (Bureau et al., 2000; Dieudonné, 1998), stellate/basket cell $\rightarrow$ Golgi cell (Dumoulin et al., 2001) and Lugaro cell $\rightarrow$ Golgi cell (Dieudonné and Dumoulin, 2000) connections, the nature of connections from mossy fibers and climbing fibers to Golgi cells remains largely to be determined.

The main function of Golgi cells is to inhibit the granule cells (Eccles et al., 1967; Palay and Chan-Palay, 1974). Each granule cell receives three to four inhibitory synapses on as many different dendrites (Hàmori and Somogyi, 1983; Jakab and Hàmori, 1988). The Golgi cell-granule cell synapses consist of small boutons located proximally to the granule cell dendritic endings, which, in turn, receive the excitatory mossy fiber terminals. Both the mossy fiber and Golgi cell terminals together with several tens of granule cell dendrites (see Ito, 1984; Palkovits et al., 1971) are included into the cerebellar glomerulus. This may also include Golgi cell basal dendrites, although this is not clear from the literature. The glomerulus is a specialized structure enwrapped into a glial sheet limiting neurotransmitter diffusion, which can determine specific effects of neurotransmitter accumulation and spillover (Barbour and Häusser, 1997). In the vestibulo-cerebellum, in addition to granule cells, the Golgi cells also inhibit the unipolar brush cells (UBC; Dugué et al., 2005).

Four anatomical aspects of circuit organization are especially interesting to understand the Golgi cell function. First, the Golgi cell axonal plexus extends 


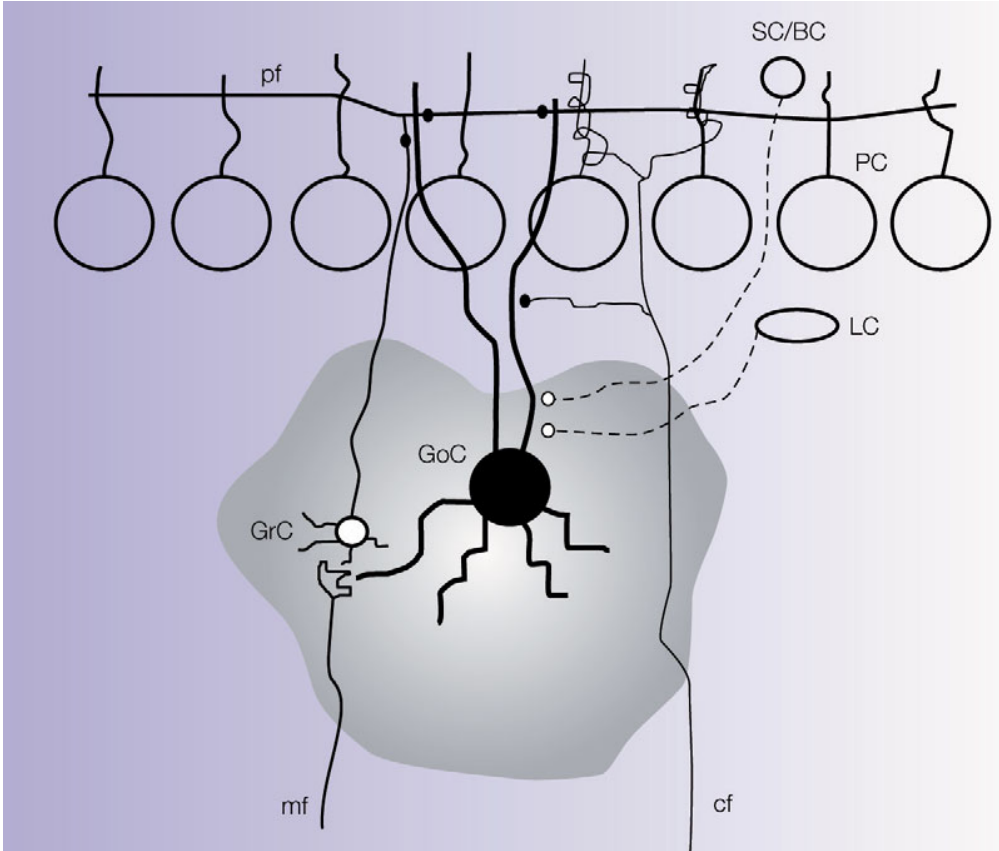

Figure 2 I Connections of the Golgi cell. The picture shows schematically the main connections of the Golgi cell (GoC) from available morphological data (Cajal, 1995; Eccles et al., 1967; Palay and Chan-Palay, 1974). The mossy fibers (mf) contact the basal GoC dendrites and the granule cell $(\mathrm{GrC})$ axon contacts the apical GoC dendrites through the parallel fibers (pf). The climbing fibers (cf) send a collateral to the GoC. The stellate cells (SC), basket cells (BC) and Lugaro Cells (LC) send inhibitory contacts to the GoC. The gray area identifies the axonal field of the GoC. It should be noted that the glomerular localization of the $\mathrm{mf}-\mathrm{GrC}$ connection has not been fully documented and that functional evidence for the cf-GoC connection is still missing.

exclusively in the granular layer and, through thin branches, can form secondary plexuses in the same or even in neighboring laminae (e.g., see Eccles et al., 1967). The broader extension of axon than basal dendrites provides the basis for lateral inhibition. Secondly, the axonal plexuses coming from different Golgi cells overlap (e.g., see Barmack and Yakhnitsa, 2008). This property is important to allow the combinatorial inhibition of granule cells, which have therefore to receive inhibition from more than one Golgi cell. Thirdly, Golgi cells emit their apical dendrites within Purkinje cell compartments (revealed by immunostaining for zebrin-2, aldolase $\mathrm{C}$ and other markers; Sillitoe et al., 2008). Therefore, Golgi cell wiring appears rather complex: through mossy fiber (and potentially climbing fiber) inputs to their dendrites, the Golgi cells are preferentially wired within microcircuits involving anatomically organized olivo-cerebellar and mossy fiber compartments (Brown and Bower, 2001; Pijpers et al., 2006; Voogd et al., 2003), while through their parallel fiber connections and their axonal plexus Golgi cells are interconnected with multiple such compartments. Another anatomical feature that has received attention is that, at variance from Purkinje cells, the structure of Golgi cell dendrites is not rigorously organized in a plane but rather it is tri-dimensional. Thus, Golgi cells may not be suited to detect ordered time sequences transmitted through the parallel fibers (Braitenberg et al., 1997). These observations combined with electrophysiological and modeling data support the view that Golgi cells can both precisely respond to topographically organized inputs and perform an extended spatio-temporal integration of parallel fiber information modulating their basal activity state (De Schutter, 2002; De Schutter and Bjaalie, 2001; Vos et al., 2000).

\section{GOLGI CELL CIRCUIT SYNAPTIC ACTIVATION}

In the last decade, cellular investigations in acute cerebellar slices have unveiled a complex organization of neurotransmitters and receptors at Golgi cell synapses (for previous reviews see Farrant and Nusser, 2005; Geurts et al., 2003) providing mechanisms suitable for regulating circuit dynamics and homeostasis. Among the major factors involved, most relevant are the expression of specific receptor sub-types in the mossy fiber-granule cell-Golgi cell circuit as well as the presence of neurotransmitter spillover in the cerebellar glomerulus.

The main excitatory inputs to Golgi cells are glutamatergic. At the mossy fiber-Golgi cell relay, preliminary observations report the involvement of AMPA (Kanichay and Silver, 2006) and NMDA receptors (L. Forti et al., unpublished observation). A more extensive investigation at the parallel fiberGolgi cell realy has revealed activation of AMPA, NMDA and kainate receptors (Bureau et al., 2000; Dieudonné, 1998; Misra et al., 2000). In particular, kainate receptors have been shown to improve temporal summation during repetitive parallel fiber activity, suggesting that this synapse is particularly sensitive to granule cell bursts (Chadderton et al., 2004; Rancz et al., 2007). It is currently unknown whether NMDA receptors, either at mossy or parallel fiber synapses, are needed to improve temporal summation (D'Angelo et al., 2004) or are related to forms of long-term synaptic plasticity. The inhibitory inputs to Golgi cells are differentiated in GABAergic and glycinergic. Pure GABAergic inputs are provided by stellate and basket cells (Dumoulin et al., 2001), while mixed GABAergic/ glycinergic inputs are formed by the Lugaro cells (Dieudonné and Dumoulin, 2000). The glycinergic IPSC component, by being expressed in variable amount and by slowing down IPSC kinetics, can fine tune the duration of Golgi cell inhibition (Dumoulin et al., 2001). Interestingly, neuromodulators have also been reported to regulate the Golgi circuit function. Serotonin activates the Lugaro cells, thereby regulating Golgi cell inhibition (Dieudonné and Dumoulin, 2000). Acetylcholine can increase non-vesicular GABA release from the Golgi cells 
contributing to set the ambient GABA level in the glomerulus and tonic inhibition of granule cells (Rossi et al., 2003; see below).

The main output from Golgi cells is GABAergic and inhibits the granule cells. The IPSCs consist in a fast and a slow component (Rossi et al., 2003) determined by differential receptor subtypes and localization (Farrant and Nusser, 2005). The $\alpha_{1}$ subunit-containing receptors $\left(\mathrm{EC}_{50}\right.$ in the $10-100 \mu \mathrm{M}$ range) are localized in the synaptic cleft and contribute mainly to determine the IPSC peak. The $\alpha_{6}$ subunit-containing receptors (primarily $\alpha_{6} \beta_{2 / 3} \gamma_{2}$ with $\mathrm{EC}_{50}$ in the $\mu \mathrm{M}$ range and $\alpha_{6} \beta_{2 / 3} \delta$, with $\mathrm{EC}_{50}$ in the $\mathrm{nM}$ range) are distributed from the synaptic junction to several hundreds of nanometers apart and contribute to enhance the IPSC tail through a spillover-dependent mechanisms (Brickley et al., 1999, 2001; Hadley and Amin, 2007; Nusser et al., 1998; Rossi and Hamann, 1998; Tia et al., 1996). This double receptor system is probably important to ensure high temporal precision in the onset of inhibition and, at the same time, efficient temporal summation during trains of Golgi cell spikes. In addition to determining phasic inhibition, Golgi cells contribute to regulate the basal granule cell input conductance by maintaining a tonic GABA concentration level inside the glomerulus (Brickley et al., 1996; Chadderton et al., 2004). The tonic level of GABA, which is also regulated by non-vesicular release and by the rate of GABA re-uptake in glial cells (Rossi et al., 2003), is thought to primarily activate high affinity $\alpha_{6} \beta_{2 / 3} \delta$ receptors (Tia et al., 1996) and to control the gain of the mossy fiber-granule cell relay (Mitchell and Silver, 2003). Although the main effects of Golgi cells on granule cells are mediated by GABA, Golgi cells also co-release glycine at their synaptic terminals (Dugué et al., 2005). Granule cells do not express glycine receptors, but it is attractive to speculate that glycine plays a role in regulating activation of granule cell NMDA receptors on their glycine binding site. Conversely, both GABA and glycine receptors are expressed in UBCs, in which Golgi cell activity generates mixed GABAergic/glycinergic responses (Dugué et al., 2005).

Metabotropic receptors also appear to regulate Golgi cell circuit functions. The mGluR2 receptors are expressed in Golgi cells (Geurts et al., 2001) and their activation enhances an inward rectifier $\mathrm{K}^{+}$current contributing to silence the Golgi cell following intense granule cell-Golgi cell transmission (Watanabe and Nakanishi, 2003). Functional evidence has also been reported for cross-talk between mossy fiber and Golgi cell terminals due to neurotransmitter spillover in the glomerulus: mGluR2 receptor activation on Golgi cell presynaptic terminals inhibits GABA release (Mitchell and Silver, 2000b), while GABA-B receptor activation on mossy fiber terminals inhibits glutamate release (Mitchell and Silver, 2000b). These reciprocal actions may sharpen the switching between excitation and inhibition of granule cells, so that once excitation prevails it will become even more strongly dominating over inhibition (and vice versa when excitation prevails). Metabotropic GABA-B receptors are also expressed in granule cells, in which they inhibit an inward rectifier $\mathrm{K}^{+}$current enhancing granule cells responsiveness upon intense Golgi cell activity (Rossi et al., 2006), probably re-establishing granule cell responsiveness in conditions of excessive inhibition.

It turns out therefore that Golgi cells are equipped with a complex set of pre- and postsynaptic receptor mechanisms, both of the ionotropic and metabotopic type, which can fine tune response dynamics under various functional conditions.

\section{GOLGI CELL ACTIVITY IN VIVO}

The activity of Golgi cells was recognized in vivo as early as in the 1960s as a component of local field potentials recorded from the granular layer upon afferent fiber stimulation (Eccles et al., 1967). Golgi cells could also be activated by stimulating the parallel fibers, thereby generating a long inhibitory tail (about $100 \mathrm{~ms}$ ) in the granular layer field response. The dynamics of the granule cells-Golgi cell circuit were explained by the simultaneous activation of both neurons through the mossy fibers, followed by activation of the feed-forward and feed-back inhibitory loops. These results have recently been reproduced in acute cerebellar slices confirming their origin from local network properties (Mapelli and D'Angelo, 2007; Maffei et al., 2002). A clear advancement in understanding Golgi cell properties has come with single unit recordings. Investigations in vivo revealed that GoCs show spontaneous rhythmic discharge both in awake (cat: 2 to $\sim 50 \mathrm{~Hz}$, Edgley and Lidierth, 1987; monkey: $10-80 \mathrm{~Hz}$, Miles et al., 1980) and anaesthetized animals (rat: 2 to $\sim 30 \mathrm{~Hz}$, Holtzman et al., 2006a,b; Schulman and Bloom, 1981; Vos et al., 1999a). The activity of Golgi cells recorded in vivo shows "loose synchrony" over hundreds of micrometers along the parasagittal axis, probably reflecting synchronization along the parallel fiber beams (Volny-Luraghi et al., 2002; Vos et al., 1999b; Tahon et al., 2005).

There are two basic patterns of mossy fiber activity that can activate the Golgi cells, namely protracted frequency-modulated discharges and short high-frequency bursts (Kase et al., 1980; Rancz et al., 2007). Accordingly, the Golgi cells present two well defined response modalities. First, Golgi cells can follow peripheral signals in a continuous fashion modulating their frequency with the intensity of the stimulus (Edgley and Lidierth, 1987; Miles et al., 1980). Secondly, Golgi cells respond to punc- 
tuate stimulation with a short burst of spikes. The response occurs very rapidly (in about $10 \mathrm{~ms}$ upon facial stimulation) and consists of one to three well timed spikes in short sequence (Vos et al., 1999a). It has been proposed that the first spike corresponds to the trigeminal input (trigemino-cerebellar mossy fibers), the second one to sensory-motor cortical input (cortico-ponto-cerebellar mossy fibers), the third to the parallel fiber input. Following this short spike bursts, the Golgi cell generates a silent pause lasting for about $100 \mathrm{~ms}$.

Recently, a significant achievement has been that of reconnecting Golgi cell behaviors observed in vivo with intrinsic electroresponsive properties analyzed in vitro through the implementation of computational models. As explained in the next section, spontaneous rhythmic discharge as well as the other typical responses recorded in vivo emerged once perturbing single cell models with balanced synaptic noise and appropriate input patterns (Solinas et al., 2007a,b). These observations argue in favor of a key role played by single cell properties in network computations. Moreover, network modeling has suggested that Golgi cell connections through parallel fibers play a substantial role in generating largely synchronized oscillation in granular layer activity (Maex and De Schutter, 1998, 2005; Maex et al., 2000).

\section{GOLGI CELL ELECTRORESPONSIVENESS IN VITRO}

In acute cerebellar slices, Golgi cells beat regularly at about $4 \mathrm{~Hz}$ at room temperature $\left(8 \mathrm{~Hz}\right.$ at $34^{\circ} \mathrm{C}$; Dieudonné, 1998; Forti et al., 2006). In addition to pacemaking, Golgi cells have revealed other relevant dynamic properties (Figures 3 and 4; Solinas et al., 2007a,b). First, the Golgi cell can be displaced from its pacemaker cycle by depolarizing currents responding with discharges at frequencies as high as $300 \mathrm{~Hz}$. These responses consist in an initial burst followed by adaptation toward a frequency depending on the intensity of the input. Secondly, after a spike or a sequence of spikes, the Golgi cell shows phase-reset, i.e., restarts pacemaking after a pause precisely corresponding to the pacemaker cycle. Thirdly, following hyperpolarization, the Golgi cell responds with rebound excitation.

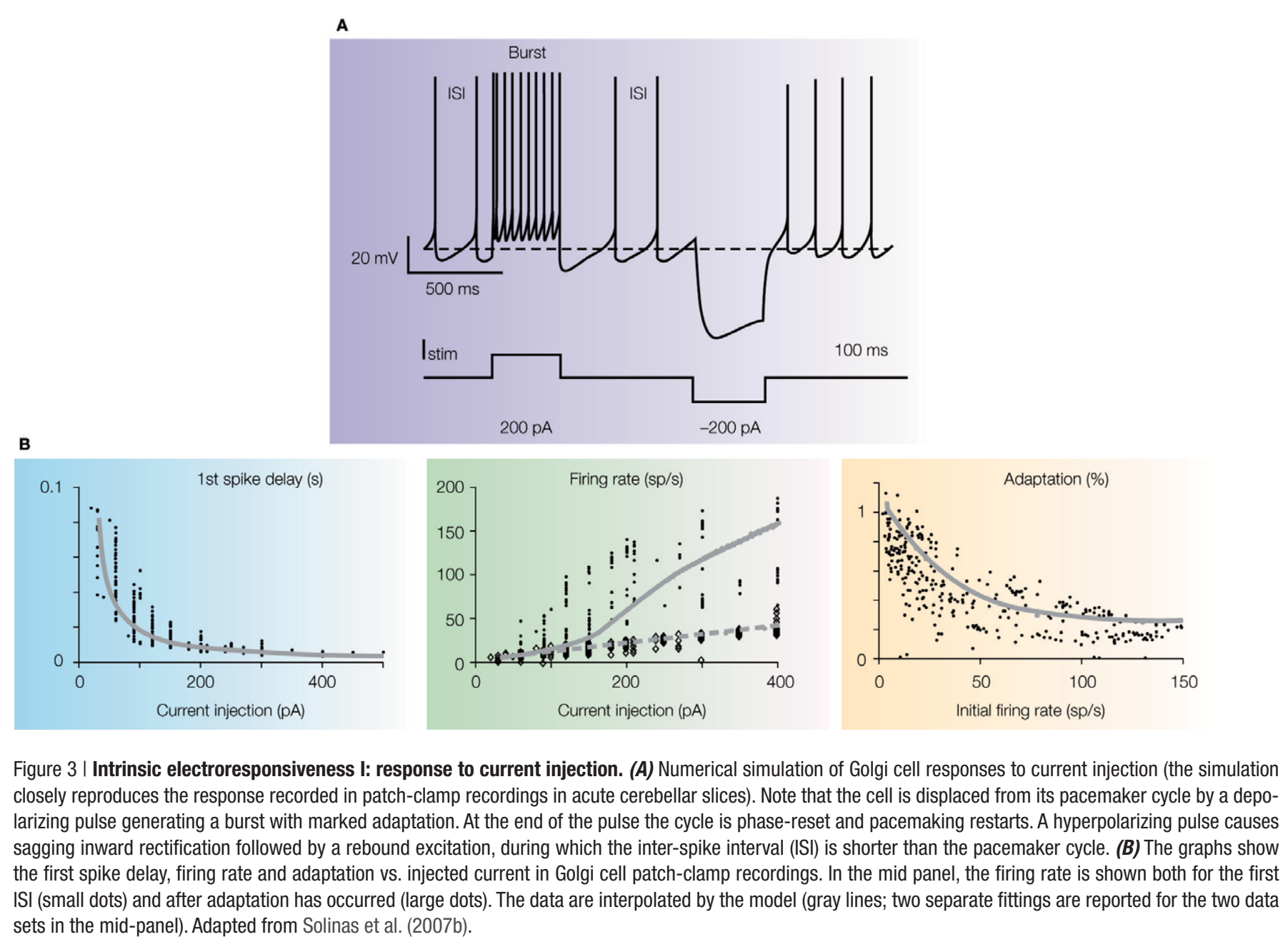


A

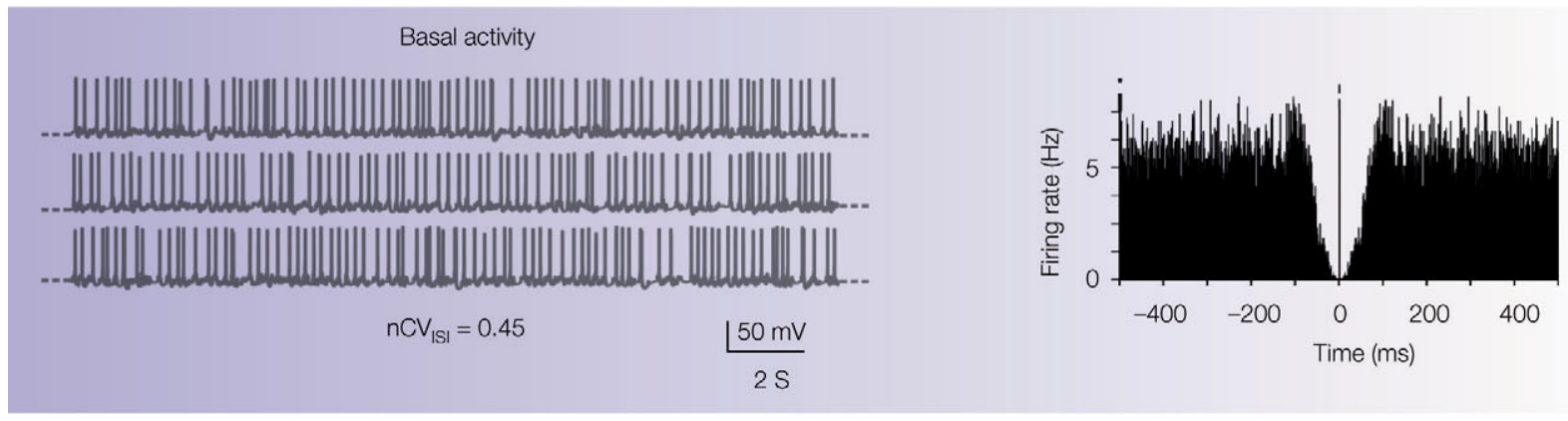

B

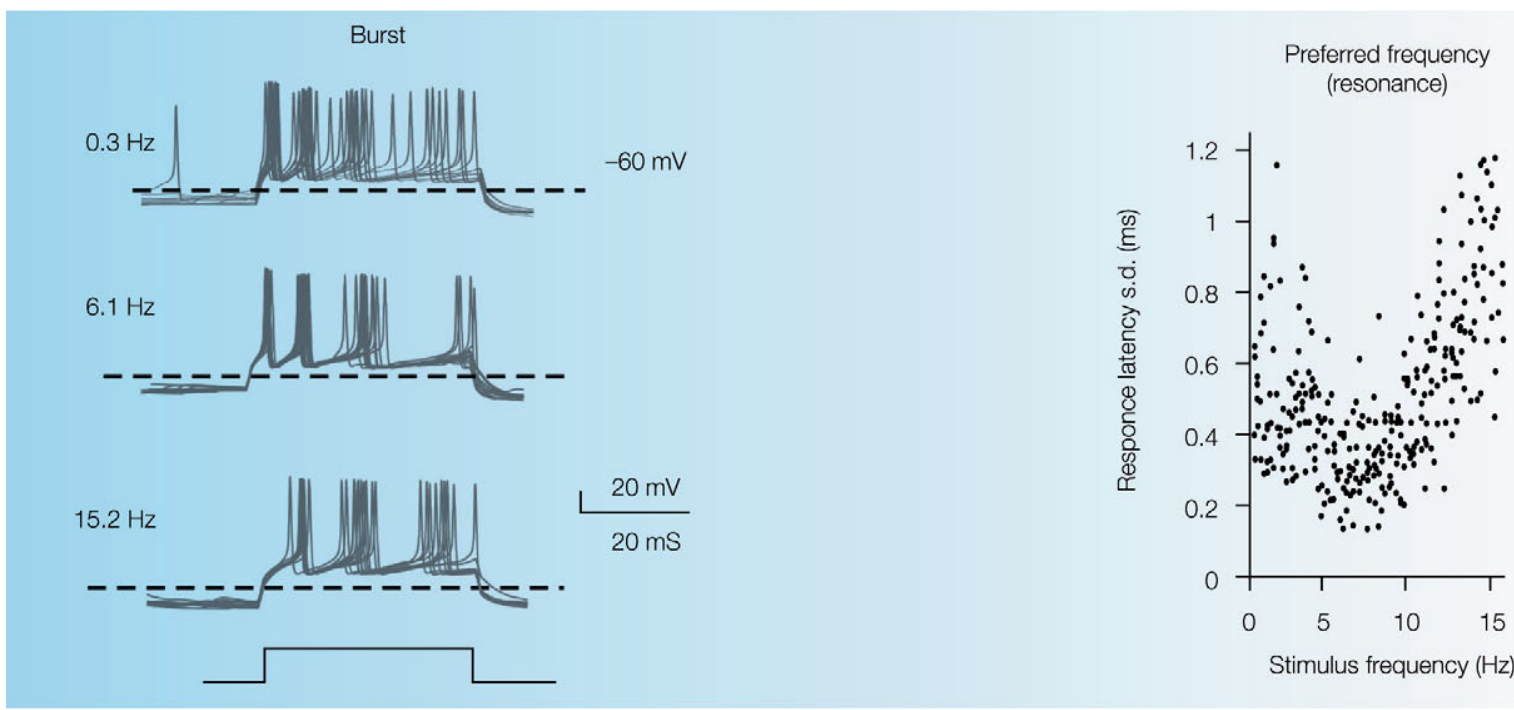

C

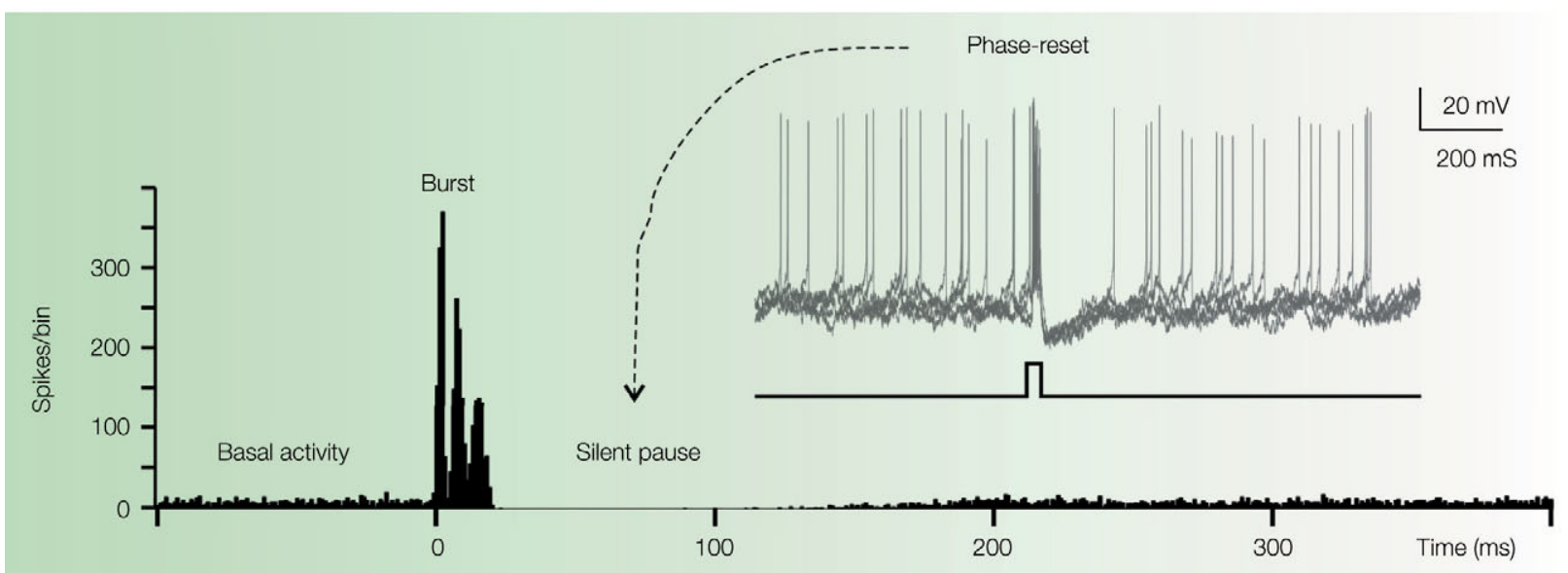

Figure 4 I Intrinsic electroresponsiveness II: matching in vivo responses. The panels report numerical simulations of Golgi cell responses added with balanced synaptic noise to simulate in vivo conditions. (A) Pacemaking. Once perturbed with balanced synaptic noise to achieve $\mathrm{nCV}_{\mid \mathrm{IS|}}=0.45$ (Vos et al., $\left.1999 \mathrm{a}\right)$ the regular pacemaking of the Golgi cell transforms into a discharge with random appearance, in which no periodic peaks can be revealed in the autocorrelation plot (right plot). (B) Preferred frequency. The Golgi cell injected with short depolarizing pulses (bottom trace) generates spike doublets-triplets very similar to those evoked by punctuate stimulation of the whisker pad. Repetition of the pulses at different frequencies reveals increased precision in first spike latency at around $5 \mathrm{~Hz}$, demonstrating a form of response resonance (right plot). (C) Phase reset. The rhythmic basal discharge of the Golgi cell is interrupted by a pulse like those shown in (B). Thereafter, the cycle is phase-reset generating a silent pause similar to that observed in vivo. The main panel shows the PSTH of responses in subsequent trials (note that the spike triplet causes three peak in the PSTH at $t=0$ followed by a period devoid of any spikes). The inset shows a collection of simulated voltage responses (gray traces). The basal beating is interrupted by spike triplets (caused by a short current pulse, black trace at the bottom) which phase-reset the response. Adapted from Solinas et al. (2007b). 
Finally, the Golgi cell response is resonant (i.e., it tends to generate its optimal response) in the theta band (the "resonance frequency" of the system for a given parameter), with enhanced precision, speed and intensity of firing for input frequencies of about $4 \mathrm{~Hz}$ at room temperature.

Golgi cell electroresponsiveness was shown to depend on a complex set of ionic channels that have been identified by means of electrophysiological, pharmacological and modeling techniques (Forti et al., 2006; Solinas et al., 2007a,b). These investigations indicate that pacemaking depends on the action of four ionic currents, $I_{\mathrm{h}}, I_{\mathrm{Na}-\mathrm{p}}$, $I_{\mathrm{K}-\mathrm{AHP}}$, and $I_{\mathrm{K} \text {-slow }}: I_{\mathrm{h}}$ brings membrane potential into the pacemaker region where the $I_{\mathrm{Na}-\mathrm{p}} / I_{\mathrm{K}-\mathrm{AHP}} / I_{\mathrm{K}-\text { slow }}$ interaction generates pacemaking. Moreover, following hyperpolarization, $I_{\mathrm{h}}$ and $I_{\mathrm{Ca}-\mathrm{LVA}}$ cause rebound excitation. In response to a depolarization, $I_{\mathrm{K}-\mathrm{A}}$ helps setting the delay for spike activation and $I_{\mathrm{Na}-\mathrm{r}}$ enhances the initial doublet, whose separation from the rest of the discharge is sharpened by adaptation caused by $I_{\mathrm{K}-\mathrm{AHP}}$ and $I_{\mathrm{K} \text {-slow }}$. Calcium-dependent regulation of ionic currents plays also a critical role. By being coupled to $I_{\mathrm{K}-\mathrm{C}}, I_{\mathrm{Ca}-\mathrm{HVA}}$ enhances the fast phase of spike AHP thereby resetting the spiking mechanism and sustaining high frequency discharge. By being coupled to $I_{\mathrm{K}-\mathrm{AHP}}, I_{\mathrm{Ca}-\mathrm{HVA}}$ enhances the slow phase of spike AHP and spike-frequency adaptation during repetitive discharge.

Although the investigation of specific ionic currents can be further extended lading to more sophisticated models, present knowledge suffices to depict a coherent mechanisms through which the Golgi cell simultaneously control pacemaking and response patterns elicited by depolarization and hyperpolarization. This in turn can explain the most relevant behaviors of the neuron reported in vivo. In summary:

1. Intrinsic pacemaking can sustain the rhythmic Golgi cell discharge in vivo. Similar to what was suggested for Purkinje cells (De Schutter and Bower, 1994; Jaeger et al., 1997; see also Shin et al., 2007), the beating may become irregular in vivo due to synaptic noise.

2. The ability to modulate response frequency upon stimulation allows the Golgi cell to follow the temporal evolution of afferent discharges, which varies with the ongoing movement (Miles et al., 1980). Moreover, firing frequency adaptation in the Golgi cell response helps explaining the shortlasting Golgi cell spiking responses to long duration stimuli observed in vivo (Tahon et al., 2005).

3. The presence of mechanisms enhancing the initial spike burst and regulating its initiation tunes the Golgi cell toward the responses to brief tactile stimuli in vivo, which is assumed to reflect differential delays in the afferent fibers (VolnyLuraghi et al. 2002; Vos et al., 1999a, 2000; see also Morissette and Bower, 1996). Again, there is a good matching between the temporal pattern of the afferent discharge and the intrinsic excitable response in Golgi cells.

4. The pacemaker mechanism provides the substrate of the silent pause observed after Golgi cell burst discharge. It should be noted that the silent pause in vivo is followed by rebound activity (Tahon et al., 2005; Vos et al., 1999a), whereas this does not occur in vitro and in the model. Rebound excitation in vivo may reflect the involvement of Golgi cell inhibition through molecular layer interneurons (Dumoulin et al., 2001; Palay and Chan-Palay, 1974), which would happen if the latter are activated together with Golgi cells and inhibit them with a short delay. In this manner, the silent pause would be enhanced allowing to engage the post-inhibitory rebound excitation of the Golgi cell. Inhibition driven by molecular layer interneurons may also explain the longlasting depressions of firing evoked by strong electrical stimuli (Holtzman et al., 2006b).

5. Golgi cell theta-frequency oscillation and resonance, together with theta-frequency resonance in granule cells (D'Angelo et al., 2001) may tune granular layer responses toward theta-frequency cortical inputs during certain sensory-motor behaviors, like active whisking (for review see Kleinfeld et al., 2006). Coherent oscillation of granular layer neurons are indeed observed in awake rats and monkeys (Hartmann and Bower, 1998, 2001; Pellerin and Lamarre, 1997).

\section{THE MULTIPLE ROLES OF GOLGI CELLS IN CEREBELLAR NETWORK CONTROL}

Together with intrinsic responsiveness, the specific arrangement of connections determines multiple effects of Golgi cell inhibition on granular layer network dynamics. Recently, we have shown that feed-forward inhibition causes a timewindowing effect, that lateral inhibition determines a center-surround organization of the granular layer response, and that local control of the granule cell excitatory-inhibitory balance determines inhibition controlled plasticity (Armano et al., 2000; D’Angelo et al., 2004; Gall et al., 2005; Hansel et al., 2001; Mapelli and D'Angelo, 2007). Moreover, feed-back granule cell inhibition combined with the broad parallel fiber convergence over numerous Golgi cells provides the substrate for generating regular synchronous oscillations over large granular layer fields (Hartmann and Bower, 1998, 2001; Maex and De Schutter, 1998; Pellerin and Lamarre, 1997). More in detail. 
CENTER-SURROUND ORGANIZATION AND INHIBITION CONTROLLED PLASTICITY

By exploiting lateral inhibition, Golgi cells can generate a center-surround organization of granular layer responses, in which an excited core is surrounded by an inhibited region (Figure 5). The evidence for this organization comes from multielectrode array recordings in vitro so that the effect was revealed over a plane. However, in vivo the effect may also extend over the third dimension, since the Golgi cell axon is distributed in a volume rather that in a plane (cf. Figure 2). It should be noted that the term center-surround is used to indicate a region of inhibition that surrounds a core of excitation (as in Rieke et al., 1997) without implying the same organization mechanisms of center-surround receptive fields of the retina. Here, the Golgi cell axon extends beyond the afferent innervation field generating lateral inhibition but is also distributed to the core, although in the core the inhibitory action is surpassed by mossy fiber excitation. Sequential activation of Golgi cells by parallel fibers, in conjunction with scattered activity in different mossy fibers, could exploit the center-surround organizing principle arranging complex spatio-temrporal geometries of signal transformation. By controlling the level of neuronal depolarization, Golgi cell synaptic inhibition can regulate NMDA channel unblock in granule cells and thereby the induction of long-term synaptic plasticity. Typically, strong inhibition would limit calcium influx causing LTD, while weak inhibition would allow intense calcium influx causing LTP (Figure 5B). This mechanisms enforces a bidirectional LTP/LTD switch (Gall et al., 2005; Lisman, 2003), which may be aided by glomerular cross-talk enhancing the switching between excitation and inhibition (Mitchell and Silver, 2000a,b).

\section{TIME-WINDOWING AND OSCILLATIONS}

By exploiting feed-forward inhibition, Golgi cells can rapidly depress or even arrest signal transmission along the mossy fiber pathway. The time window typically extends for about $5 \mathrm{~ms}$ (accounting for the delay of Golgi cell activation and IPSC generation in granule cells) and allows the granule cells to fire one to two spikes in response to a single mossy fiber stimulus (Figures 5A,B). By exploiting feed-back inhibition, Golgi cells can reinforce depression of signal transmission along the mossy fiber pathway with a delay determined by the granule cell reaction times. The feed-back approximately takes another $5 \mathrm{~ms}$, needed to activate a

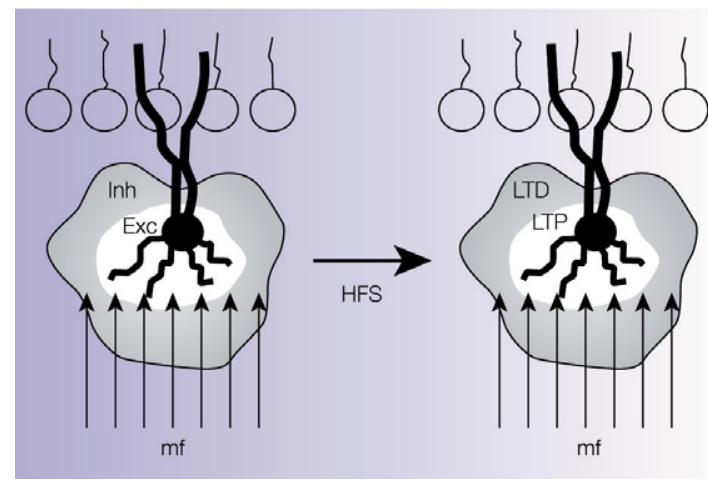

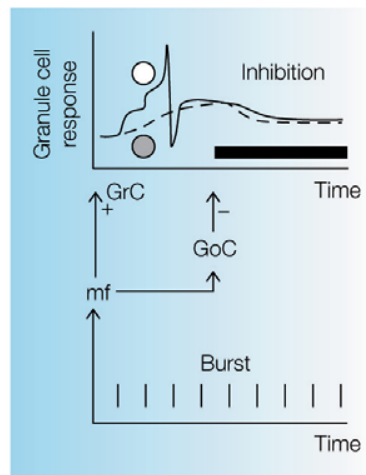

Figure 5 | Spatio-temporal transformations based on integrated regulation of timing and plasticity. This schematic reconstruction, inspired by the data reported by Mapelli and D'Angelo (2007) and Nieus et al. (2006), illustrates the role of Golgi cells in controlling spatio-temporal reconfiguration of granular layer activity and long-term synaptic plasticity at the mossy fiber granule cell relay. (A) The center-surround organization (white-gray areas) of excitation and inhibition determines a biphasic response to high-frequency stimulation trains in the mossy fibers, such that the core tends to generate LTP and the surround to generate LTD. The Golgi cell is shown in black. (B) The picture illustrates the expected effect of a mossy fiber burst (bottom) entering into the granular layer. If one assumes that LTP and LTD have been distributed in center-surround as shown in ( $\boldsymbol{A}$ ), then the granular layer output will occur with delays that are different for the granule cells in the two regions. Actually, the center and the surround will act as differential delay lines due to the fact that LTP anticipates and LTD delays granule cell output responses to mossy fiber bursts. The top graph shows the idealized output response for two granule cells (solid line for a granule cell with LTP, dashed line for a granule cell with LTD). The regulation of delays occurs across the inhibitory window set by the Golgi cell (black line), which is also coactivated by the mossy fiber burst but inhibits granule cells with a delay caused by its own excitation time and the additional synapse inbetween. Mossy fiber-granule cell LTP effectively anticipates spike generation before the arrival of Golgi cell inhibition. Conversely, mossy fiber-granule cell LTD slows down membrane potential growth to the point that spikes are not generated before the arrival of Golgi cell inhibition, which will further slow down depolarization eventually preventing any spike generation. Thus, the Golgi cell in combination with mossy fiber-granule cell plasticity endows the granular layer with the properties of a spatio-temporal filter. 
spike in granule cells and transmit it at the parallel fiber-Golgi cell synapse (see Mapelli and D'Angelo, 2007; Vos et al., 1999a). In the presence of a continuous input, feed-forward inhibition can give rise to oscillations, since, once granule cells are excited, they can activate the Golgi cell switching off their own excitation. When the inhibitory action is terminated, the cycle restarts.

These observations are complemented by several modeling studies, which also indicate that the Golgi cell system can produce time-windowing and cause synchronous oscillations in granular layer activity (Maex and De Schutter, 1998). In these spiking cerebellar networks the granule cells can generate a variety of temporal dynamics under inhibitory control of the Golgi cells (Medina and Mauk, 2000). Oscillations at theta-frequency (Hartmann and Bower, 1998, 2001; Pellerin and Lamarre, 1997) may require inputs on the same band from extracerebellar areas or signal reentry from the deep cerebellar nuclei (Kistler and De Zeeuw, 2003; Yamazaki and Tanaka, 2007).

\section{COMPUTATIONAL IMPLICATIONS AND CONCLUSIONS}

The observations presented above indicate that Golgi cells are involved in three main control processes of granular layer activity that could have profound implications for the cerebellar function.

\section{INTEGRATED REGULATION OF SPATIO-TEMPORAL SIGNAL TRANSFORMATIONS AND PLASTICITY}

Golgi cells lay at the core of a complex process integrating synaptic inhibition and long-term synaptic plasticity (Figure 5). The center-surround organization of LTP and LTD determined by Golgi cells can generate differential delay lines due to the fact that LTP anticipates and LTD delays granule cell responses to mossy fiber bursts (Nieus et al., 2006). Interestingly, the time-window set by Golgi cell feed-forward inhibition will extend this mechanism. Indeed, synaptic depolarization generated by synapses with LTP will lead to spikes before inhibition starts, while synaptic depolarization generated by synapses with LTD will collide with inhibition and spikes will therefore by prevented. Thus, extending a prediction of theoretical network analysis (De Schutter and Bjaalie, 2001; Medina and Mauk, 2000), the Golgi cell endows the granular layer with the properties of a spatio-temporal filter determining precisely timed activation of Purkinje cell assemblies (Bower, 2002; Lu et al., 2005). In addition, by controlling the spatio-temporal pattern of spikes emitted by granule cells, Golgi cells could also regulate the development of short-term (Isope and Barbour, 2002; Sims and Hartell, 2005) and long-term synaptic plasticity (Casado et al., 2002; Hansel et al., 2001) at the corresponding parallel fiber synapses. By regulating synaptic plasticity, Golgi cells may take part to cerebellar receptive field re-shaping following patterned sensory stimulation (Jorntell and Ekerot, 2002).

\section{CIRCUIT HOMEOSTASIS}

Golgi cells take part to homeostatic mechanisms. A first consideration is that, if input trains saturate granular layer plasticity, this would be inefficient for controlling information processing (this issue was envisaged by Marr as early as in 1969). In fact, the redistribution of LTP and LTD in neighboring granular layer areas caused by Golgi cells maintains the circuit in homeostatic balance (while activity is enhanced in certain areas, it is reduced in others). Secondly, if Golgi cell activity is too strong, then some granule cells would be fully inhibited with detrimental effects on the computational capacity of the circuit as a whole (again, Marr in 1969 predicted that the sparseness of granule cell coding had to be precisely regulated and never reduced below a critical limit; see also Schweighofer et al., 2001). Interestingly, strong Golgi cell activity can generate long-term enhancement of granule cell excitability by activating GABA-B receptors and inhibiting an inward rectifier $\mathrm{K}^{+}$current (Rossi et al., 2006), such that too strong and prolonged inhibition is compensated by increased granule cell excitability. Another mechanism that can contribute to this regulation is mGluR receptors-mediated enhancement of an inward rectifier $\mathrm{K}^{+}$current at the parallel fiber synapse, which contributes to silence the Golgi cell following intense granule cell-Golgi cell transmission (Watanabe and Nakanishi, 2003). Thirdly, if Golgi cell inhibition is too week, the granule cells would be over-excited. In fact, in mice with genetic ablation of Golgi cells, NMDA receptor transmission at the mossy fiber-granule cell synapse is down-regulated (Watanabe et al., 1998), with the likely consequences of reducing EPSP temporal summation (D'Angelo et al., 1995) and LTP (Rossi et al., 2002) thereby preventing granule cell over-excitation.

\section{LARGE-SCALE OSCILLATIONS AND SYNCHRONIZATION}

On the larger scale of cerebellar microcircuits (see Brown and Bower, 2001; Pijpers et al., 2006; Voogd et al., 2003), Golgi cells are predicted to operate an extensive spatio-temporal signal integration. On the one hand, the Golgi cells can improve channeling of information toward overlaying Purkinje cells (Cohen and Yarom, 1998). On the other hand, since the axonal fields of several Golgi cells can overlap and extend outside the limits of the afferent field (Barmack and Yakhnitsa, 2008; Sillitoe 
et al., 2008), cerebellar operations can be integrated across different functional modules. Another element of linkage between modules is represented by the parallel fibers, which interconnect Golgi cell along the longitudinal axis (Maex and De Schutter, 1998; Vos et al., 1999b). Together with these structural features, the preferential response of Golgi cells at theta frequency may play a central role in determining granular layer synchronous oscillations in the same frequency-band (Hartmann and Bower, 1998, 2001; Lu et al., 2005; Pellerin and Lamarre, 1997). Interestingly, the Golgi cells may also represent a connection element between the mossy fiber input and the other major afferent system, that generated by the inferior olive (Yarom and Cohen, 2002), both through the putative climbing fiber Golgi cell connection and through the inhibitory interneurons of the molecular layer, the stellate cells, which inhibit the Golgi cells (Barmack and Yakhnitsa, 2008).

It is then attractive to speculate on to how the Golgi cells might affect cerebellar computations as a whole. In earlier descriptions, Golgi cell mediated inhibition was proposed to regulate the codon size (Albus, 1971; Marr, 1969) and then to assist processing of input temporal patterns (ChapeauBlondeau and Chauvet, 1991; Fujita, 1982). In fact, by combining lateral inhibition with Hebbian learning, Golgi cells may regulate competition between neighboring areas causing the emergence of self-organized topology, feature abstraction and generalization (Kohonen, 1984; see also Rieke et al., 1997; Singer, 1999). By controlling granular layer theta-frequency oscillations, the Golgi cell may tune communication with extracerebellar structures like the cerebral cortex and enhance responses to specific sensori-motor circuits (Buzsaki, 2006; Kistler and De Zeeuw, 2003; Kleinfeld et al., 2006). By synchronizing extended granular layer areas, the Golgi cell may render the cerebellar response cross-modal, implementing the integrative functions that the cerebellum is thought to operate in sensori-motor coordination (De Schutter and Bjaalie, 2001; Vos et al., 1999a, 2000). It can therefore be anticipated that functional impairment of Golgi cells would cause relevant damage to cerebellar functions. Indeed mice, in which Golgi cells have been selectively inactivated by inducible viral vectors, showed impaired motor coordination in compound movements revealing a deficit in cerebellar coordination (Watanabe et al., 1998). There is another example, in which Golgi cell functioning was altered and motor coordination was impaired, the stargazer mutation (Richardson and Leitch, 2002). However, in that case Purkinje and stellate cells were also affected so that the responsibility of Golgi cells could not be isolated.

In conclusion, there is extensive experimental and theoretical evidence indicating that Golgi cells are critical to organize output granule cell spike activities in multiple spatio-temporal domains. These spikes will then be conveyed through the cerebellar network determining the subsequent computation taking place in the entire neuronal chain passing through Purkinje cells and deep cerebellar nuclei neurons. A further understanding of the impact of Golgi cells on cerebellar network activity will require new experimental testing in vitro and in vivo using electrophysiological and imaging techniques able to visualize circuit activities, the development of genetic mutants selectively affecting the Golgi cell circuit and the reconstruction of network computations with large-scale network simulations.

\section{CONFLICT OF INTEREST STATEMENT}

The authors declare that the research was conducted in the absence of any commercial or financial relationships that could be construed as a potential conflict of interest.

\section{ACKNOWLEDGEMENTS}

Supported by EU projects SENSOPAC and CYBERRAT and by the CNISM (Consorzio Nazionale Interuniversitario per le Scienze Fisiche della Materia) project NEUROIMAGE. Particular thanks to all the members of my laboratory in Pavia and especially to those working on the Golgi cell and its synapses (Paola Rossi, Lia Forti, Sergio Solinas, Jonathan Mapelli, Elisabetta Cesana, Daniela Gandolfi) as well as to Stephanne Dieudonné and Erik De Schutter for their contribution to experimental results and continued discussion on the Golgi cell function.

\section{REFERENCES}

Albus, J. S. (1971). A theory of cerebellar function. Math. Biosci. 10, 25-61.

Andersen, B. B., Korbo, L., and Pakkenberg, B. (1992). A quantitative study of the human cerebellum with unbiased stereological techniques. J. Comp. Neurol. 326, 549-560.

Armano, S., Rossi, P., Taglietti, V., and D'Angelo, E. (2000). Long-term potentiation of intrinsic excitability at the mossy fiber-granule cell synapse of rat cerebellum. J. Neurosci. 20, 5208-5216.

Barbour, B., and Häusser, M. (1997). Intersynaptic diffusion of neurotransmitter. Trends Neurosci. 20, 377-384.

Barmack N. H., and Yakhnitsa, V. (2008). Functions of interneurons in mouse cerebellum. J. Neurosci. $28,1140-1152$.
Bower, J. M. (2002). The organization of cerebellar cortical circuitry revisited: implications for function. Ann. N. Y. Acad. Sci. 978, 135-155.

Braitenberg, V., Heck, D., and Sultan, F. (1997). The detection and generation of sequences as a key to cerebellar function. Experiments and theory. Behav. Brain Sci. 20, 229-245.

Brickley, S. G., Cull-Candy, S. G., and Farrant, M. (1996). Development of a tonic form of synaptic 
inhibition in rat cerebellar granule cells resulting from persistent activation of $\mathrm{GABA}_{\mathrm{A}}$ receptors. J. Physiol. 497, 753-759.

Brickley, S. G., Cull-Candy, S. G., and Farrant, M. (1999). Single-channel properties of synaptic and extrasynaptic $\mathrm{GABA}_{\mathrm{A}}$ receptors suggest differential targeting of receptor subtypes. J. Neurosci. 19, 2960-2973.

Brickley, S. G., Revilla, V., Cull-Candy, S. G., Wisden, W., and Farrant, M. (2001). Adaptive regulation of neuronal excitability by a voltage-independent potassium conductance. Nature 409, 88-92.

Brown, I. E., and Bower, J. M. (2001). Congruence of mossy fiber and climbing fiber tactile projections in the lateral hemispheres of the rat cerebellum. J. Comp. Neurol. 429, 59-70.

Bureau, I., Dieudonné, S., Coussen, F., and Mulle, C. (2000). Kainate receptor-mediated synaptic currents in cerebellar Golgi cells are not shaped by diffusion of glutamate. Proc. Natl. Acad. Sci. USA 97, 6838-6843.

Buzsaki, G. (2006). Rhythms of the Brain. Oxford, NY, Oxford University Press.

Cajal, S. R. Y. $(1987,1989,1904)$. Textura del sistema nervioso del hombre y de los vertebrados (3 volumenes). Madrid, Imprenta y Librería de Nicolás Moya.

Cajal, S. R. Y. (1995). Histology of the nervous system of man and vertebrates. Oxford, NY, Oxford University Press.

Casado, M., Isope, P., and Ascher, P. (2002). Involvement of presynaptic N-methyl-D-aspartate receptors in cerebellar long-term depression. Neuron 33, 123-130.

Chadderton, P., Margrie, T. W., and Häusser, M. (2004). Integration of quanta in cerebellar granule cells during sensory processing. Nature 428 , 856-860.

Chapeau-Blondeau, F., and Chauvet, G. (1991). A neural network model of the cerebellar cortex performing dynamic associations. Biol. Cybern. $65,267-279$

Cohen, D., and Yarom, Y. (1998). Patches of synchronized activity in the cerebellar cortex evoked by mossy-fiber stimulation: questioning the role of parallel fibers. Proc. Natl. Acad. Sci. USA 95, 15032-15036.

D’Angelo, E., De Filippi, G., Rossi, P., and Taglietti, V. (1995). Synaptic excitation of individual rat cerebellar granule cells in situ: evidence for the role of NMDA receptors. J. Physiol. (Lond.) 484, 397-413.

D’Angelo, E., Nieus, T., Maffei, A., Armano, S., Rossi, P., Taglietti, V., Fontana, A., and Naldi, G. (2001). Theta-frequency bursting and resonance in cerebellar granule cells: experimental evidence and modeling of a slow $\mathrm{K}^{+}$-dependent mechanism. J. Neurosci. 21, 759-770.

D’Angelo, E., Rossi, P., Gall, D., Prestori, F., Nieus, T., Maffei, A., and Sola, E. (2004). Long-term potentiation of synaptic transmission at the mossy fiber-granule cell relay of cerebellum. Prog. Brain Res. 248, 71-80.

De Schutter, E. (2002). Cerebellar cortex: computation by extrasynaptic inhibition. Curr. Biol. 12,363-365.

De Schutter, E., and Bjaalie, J. G. (2001). Coding in the granular layer of the cerebellum. Prog. Brain Res. 130, 279-296.
De Schutter, E., and Bower, J. M. (1994). An active membrane model of the cerebellar Purkinje cell: II. Simulation of synaptic responses. J. Neurophysiol. 71, 401-419.

Dieudonné, S. (1998). Submillisecond kinetics and low efficacy of parallel fibre-Golgi cell synaptic currents in the rat cerebellum. J. Physiol. 510, 845-866.

Dieudonné, S., and Dumoulin, A. (2000). Serotonindriven long-range inhibitory connections in the cerebellar cortex. J. Neurosci. 20, 1837-1848.

Dugué, G. P., Dumoulin, A., Triller, A., and Dieudonné, S. (2005). Target-dependent use of co-released inhibitory transmitters at central synapses. J. Neurosci. 25, 6490-6498.

Dumoulin, A., Triller, A., and Dieudonné, S. (2001). IPSC kinetics at identified GABAergic and mixed GABAergic and glycinergic synapses onto cerebellar Golgi cells. J. Neurosci. 21, 6045-6057.

Eccles, J. C., Ito, M., and Szentagothai, J. (1967). The Cerebellum as a Neuronal Machine. Berlin, Springer.

Edgley, S. A., and Lidierth, M. (1987). The discharges of cerebellar Golgi cells during locomotion in the cat. J. Physiol. 392, 315-332.

Farrant, M., and Nusser, Z. (2005). Variations on an inhibitory theme: phasic and tonic activation of GABA A receptors. Nat. Rev. Neurosci. 6, 215-229.

Forti, L., Cesana, E., Mapelli, J., and D’Angelo, E. (2006). Ionic mechanisms of autorhythmic firing in rat cerebellar Golgi cells. J. Physiol. 574, $711-729$.

Fujita, M. (1982). Adaptive filter model of the cerebellum. Biol. Cybern. 45, 195-206.

Gall, D., Prestori, F., Sola, E., D’Errico, A., Roussel, C., Forti, L., Rossi, P., and D'Angelo, E. (2005). Intracellular calcium regulation by burst discharge determines bidirectional long-term synaptic plasticity at the cerebellum input stage. J. Neurosci. 25, 4813-4822.

Geurts, F. J., De Schutter, E., and Dieudonné, S. (2003). Unraveling the cerebellar cortex: cytology and cellular physiology of large-sized interneurons in the granular layer. Cerebellum 2, 290-229.

Geurts, F. J., Timmermans, J., Shigemoto, R., and De Schutter, E. (2001). Morphological and neurochemical differentiation of large granular layer interneurons in the adult rat cerebellum. Neuroscience 104, 499-512.

Golgi, C. (1883). Sulla fina anatomia degli organi centrali del sistema nervoso IV. Sulla fina anatomia delle circonvoluzioni cerebellari. Riv. Sper. Freniatr. Med. Leg. Alien. Ment. 9, 1-17.

Golgi, C. (1906). The neuron doctrine: theory and facts. Nobel Lectures: Physiology or Medicine 1901-1921, pp. 189-217.

Hadley, S. H., and Amin, J. (2007). Rat a6b2d GABA receptors exhibit two distinct and separable agonist affinities. J. Physiol. 581, 1001-1018.

Hàmori, J., and Somogyi, J. (1983). Differentiation of cerebellar mossy fiber synapses in the rat: a quantitative electron microscope study. J. Comp. Neurol. 220, 365-377.

Hansel, C., Linden, D. J., and D'Angelo, E. (2001). Beyond parallel fiber LTD: the diversity of synaptic and non-synaptic plasticity in the cerebellum. Nat. Neurosci. 4, 467-475.
Hartmann, M. J., and Bower, J. M. (1998). Oscillatory activity in the cerebellar hemispheres of unrestrained rats. J. Neurophysiol. 80, 1598-1604.

Hartmann, M. J., and Bower, J. M. (2001). Tactile responses in the granule cell layer of cerebellar folium crus IIa of freely behaving rats. J. Neurosci. 21,3549-3563.

Holtzman, T., Mostofi, A., Phuah, C. L., and Edgley, S. A. (2006a). Cerebellar Golgi cells in the rat receive multimodal convergent peripheral inputs via the lateral funiculus of the spinal cord. J. Physiol. 577, 69-80.

Holtzman, T., Rajapaksa, T., Mostofi, A., and Edgley, S. A. (2006b). Different responses of rat cerebellar Purkinje cells and Golgi cells evoked by widespread convergent sensory inputs. J. Physiol. $574,491-507$.

Isope, P., and Barbour, B. (2002). Properties of unitary granule cell $\rightarrow$ Purkinje cell synapses in adult rat cerebellar slices. J. Neurosci. 22, 9668-9678.

Ito, M. (1984). The Cerebellum and Neural Control. New York, NY, Raven Press.

Jaeger, D., De Schutter, E., and Bower, J. M. (1997). The role of synaptic and voltage-gated currents in the control of Purkinje cell spiking: a modeling study. J. Neurosci. 17, 91-106.

Jakab, R. L., and Hàmori, J. (1988). Quantitative morphology and synaptology of cerebellar glomeruli in the rat. Anat. Embryol. 179, 81-88.

Jorntell, H., and Ekerot, C. F. (2002). Reciprocal bidirectional plasticity of parallel fiber receptive fields in cerebellar Purkinje cells and their afferent interneurons. Neuron 34, 797-806.

Kanichay R. T., and Silver, R. A. (2006). Putative mossy fibre input resets spontaneous Golgi cell firing with high efficacy. FENS Abstr. 3, A191.8.

Kase, M., Miller, D. C., and Noda, H. (1980). Discharges of Purkinje cells and mossy fibres in the cerebellar vermis of the monkey during saccadic eye movements and fixation. J. Physiol. 300, 539-555.

Kistler, W. M., and De Zeeuw, C. (2003). Time windows and reverberating loops: a reverse engineering approach to cerebellar function. Cerebellum 2, 44-54.

Kleinfeld, D., Ahissar, E., and Diamond, M. E. (2006). Active sensation: insights from the rodent vibrissa sensorimotor system. Curr. Opin. Neurobiol. 16 435-444.

Kohonen, T. (1984). Self-Organization and Associative Memory. New York, NY, Springer Verlag.

Lisman, J. E. (2003). Long-term potentiation: outstanding questions and attempted synthesis. Philos. Trans. R. Soc. Lond., B, Biol. Sci. 358, 829-842.

Lu, H., Hartmann, M. J., and Bower, J. M. (2005). Correlations between Purkinje cell single unit activity and simultaneously recorded field potentials in the immediately underlying granule cell layer. J. Neurophysiol. 94, 1849-1860.

Maex, R., and De Schutter, E. (1998). Synchronization of Golgi and granule cell firing in a detailed network model of the cerebellar granule cell layer. J. Neurophysiol. 80, 2521-2537.

Maex, R., and De Schutter, E. (2005). Oscillations in the cerebellar cortex: a prediction of their frequency bands. Prog. Brain Res. 148, 181-188. 
Maex, R., Vos, B. P., and De Schutter, E. (2000). Weak common parallel fibre synapses explain the loose synchrony observed between rat cerebellar Golgi cells. J. Physiol. 523, 175-192.

Maffei, A., Prestori, F., Rossi, P., Taglietti, V., and D'Angelo, E. (2002). Presynaptic current changes at the mossy fiber-granule cell synapse of cerebellum during LTP. J. Neurophysiol. 88 , 627-638

Mapelli, J., and D'Angelo, E. (2007). The spatial organization of long-term synaptic plasticity at the input stage of cerebellum. J. Neurosci. 27, 1285-1296.

Marr, D. (1969). A theory of cerebellar cortex. J. Physiol. 202, 437-470.

Medina, J. F., and Mauk, M. D. (2000). Computer simulation of cerebellar information processing. Nat. Neurosci. 3, 1205-1211.

Miles, F.A., Fuller, J.H., Braitman, D. J., and Dow, B. M. (1980). Long-term adaptive changes in primate vestibuloocular reflex. III. Electrophysiological observations in flocculus of normal monkeys. J. Neurophysiol. 43, 1437-1476.

Misra, C., Brickley, S. G., Farrant, M., and CullCandy, S. G. (2000). Identification of subunits contributing to synaptic and extrasynaptic NMDA receptors in Golgi cells of the rat cerebellum. J. Physiol. 524, 147-162.

Mitchell, S. J., and Silver, R. A. (2000a). Glutamate spillover suppresses inhibition by activating presynaptic mGluRs. Nature 404, 498-502.

Mitchell, S. J., and Silver, R. A. (2000b). GABA spillover from single inhibitory axons suppresses low-frequency excitatory transmission at the cerebellar glomerulus. J. Neurosci. 20, 8651-8658.

Mitchell, S. J., and Silver, R. A. (2003). Shunting inhibition modulates neuronal gain during synaptic excitation. Neuron 38, 433-445.

Morissette, J., and Bower, J. M. (1996). Contribution of somatosensory cortex to responses in the rat cerebellar granule cell layer following peripheral tactile stimulation. Exp. Brain Res. 109, 240-250.

Nieus, T., Sola, E., Mapelli, J., Saftenku, E., Rossi, P., and D'Angelo, E. (2006). LTP regulates burst initiation and frequency at mossy fiber-granule cell synapses of rat cerebellum: experimental observations and theoretical predictions. J. Neurophysiol. 95, 686-699.

Nusser, Z., Sieghart, W., and Somogyi, P. (1998). Segregation of different GABA receptors to synaptic and extrasynaptic membranes of cerebellar granule cells. J. Neurosci. 18, 1693-1703.

Palay, S. L., and Chan-Palay, V. (1974). Cerebellar Cortex. New York, NY, Springer-Verlag.

Palkovits, M., Magyar, P., and Szentàgothai, J. (1971). Quantitative histological analysis of the cerebellar cortex in the cat. II. Cell numbers and densities in the granular layer. Brain Res. 32, 15-30.

Pellerin, J. P., and Lamarre, Y. (1997). Local field potential oscillations in primate cerebellar cortex during voluntary movement. J. Neurophysiol. 78 , 3502-3507.

Pichitpornchai, C., Rawson, J. A., and Rees, S. (1994). Morphology of parallel fibres in the cerebellar cortex of the rat: an experimental light and electronmicroscopic study with biocytin. J. Comp. Neurol. 342, 206-220.
Pijpers, A., Apps, R., Pardoe, J., Voogd, J., and Ruigrok, T. J. H. (2006). Precise spatial relationships between mossy fibers and climbing fibers in rat cerebellar cortical zones. J. Neurosci. 26, 12067-12080.

Rancz, E. A., Ishikawa, T., Duguid, I., Chadderton, P., Mahon, S., and Häusser, M. (2007). High-fidelity transmission of sensory information by single cerebellar mossy fibre boutons. Nature 450, $1245-1248$

Richardson, C. A., and Leitch, B. (2002). Cerebellar Golgi, Purkinje, and basket cells have reduced gamma-aminobutyric acid immunoreactivity in stargazer mutant mice. J. Comp. Neurol. 453, 85-99.

Rieke, F., Warland, D., de Ruyter van Stevenink, R., and Bialek, W. (1997). Spikes. London, MIT Press.

Rossi, D. J., and Hamann, M. (1998). Spillovermediated transmission at inhibitory synapses promoted by high affinity alpha6 subunit $\mathrm{GABA}_{\mathrm{A}}$ receptors and glomerular geometry. Neuron 20, 783-795.

Rossi, D. J., Hamann, M., and Attwell, D. (2003). Multiple modes of GABAergic inhibition of rat cerebellar granule cells. J. Physiol. 548, 97-110.

Rossi, P., Mapelli, L., Roggeri, L., Gall, D., de Kerchove d'Exaerde, A., Schiffmann, S. N., Taglietti, V., and D’Angelo, E. (2006). Long-lasting inhibition of constitutive inward rectifier currents in cerebellar granule cells by synaptic activation of $\mathrm{GABA}_{\mathrm{B}}$ receptors. Eur. J. Neurosci. 24, 419-432.

Rossi, P., Sola, E., Taglietti, V., Borchardt, T., Steigerwald, F., Utvik, K., Ottersen, O. P., Kohr, G., and D'Angelo, E. (2002). Cerebellar synaptic excitation and plasticity require proper NMDA receptor positioning and density in granule cells. J. Neurosci. 22, 9687-9697.

Schulman, J. A., and Bloom F. E. (1981). Golgi cells of the cerebellum are inhibited by inferior olive activity. Brain Res. 210, 350-355.

Schweighofer, N., Doya, K., and Lay, F. (2001). Unsupervised learning of granule cell sparse codes enhances cerebellar adaptive control. Neuroscience 103, 35-50.

Shin, S.-L., Hoebeek, F. E., Schonewille, M., De Zeeuw, C. I., Aertsen, A., and De Schutter, E. (2007). Regular patterns in cerebellar Purkinje cell simple spike trains. PLoS ONE 2, e485.

Shinoda, Y., Sugihara, I., Wu, H. S., and Sugiuchi, Y. (2000). The entire trajectory of single climbing and mossy fibers in the cerebellar nuclei and cortex. Prog. Brain Res. 124, 173-186.

Sillitoe, R. V., Chung, S. H., Fritschy, J. M., Hoy, M., and Hawkes, R. (2008). Golgi cell dendrites are restricted by Purkinje cell stripe boundaries in the adult mouse cerebellar cortex. J. Neurosci. 28 , 2820-2826.

Sims, R. E., and Hartell, N. A. (2005). Differences in transmission properties and susceptibility to long-term depression reveal functional specialization of ascending axon and parallel fiber synapses to Purkinje cells. J. Neurosci. 25, 3246-3257.

Singer, W. (1999). Time as coding space? Curr. Opin. Neurobiol. 9, 189-194.

Solinas, S., Forti, L., Cesana, E., Mapelli, J., De Schutter, E., and D'Angelo, E. (2007a). Computational reconstruction of pacemaking and intrinsic electroresponsiveness in cerebellar Golgi cells. Front. Neurosci. 1-2, 1-12.

Solinas, S., Forti, L., Cesana, E., Mapelli, J., De Schutter, E., and D'Angelo, E. (2007b). Fastreset of pacemaking and theta-frequency resonance patterns in cerebellar Golgi cells: simulations of their impact in vivo. Front. Neurosci. 1-4, 1-9.

Tahon, K., Volny-Luraghi, A., and De Schutter, E. (2005). Temporal characteristics of tactile stimuli influence the response profile of cerebellar Golgi cells. Neurosci. Lett. 390, 156-161.

Tia, S., Wang, J. F., Kotchabhakdi, N., and Vicini, S. (1996). Distinct deactivation and desensitization kinetics of recombinant $\mathrm{GABA}_{\mathrm{A}}$ receptors. Neuropharmacology 35, 1375-1382.

Volny-Luraghi, A., Maex, R., Vos, B. P., and De Schutter, E. (2002). Peripheral stimuli excite coronal beams of Golgi cells in rat cerebellar cortex. Neuroscience 113, 363-373.

Voogd, J., Pardoe, J., Ruigrok, T. J. H., and Apps, R. (2003). The distribution of climbing and mossy fiber collateral branches from the copula pyramidis and the paramedian lobule: congruence of climbing fiber cortical zones and the pattern of zebrin banding within the rat cerebellum. J. Neurosci. 23, 4645-4656.

Vos, B. P., Volny-Luraghi, A., and De Schutter, E. (1999a). Cerebellar Golgi cells in the rat: receptive fields and timing of responses to facial stimulation. Eur. J. Neurosci. 11, 2621-2634.

Vos, B. P., Maex, R., Volny-Luraghi, A., and De Schutter, E. (1999b). Parallel fibers synchronize spontaneous activity in cerebellar Golgi cells. J. Neurosci. 19, RC6.

Vos, B. P., Volny-Luraghi, A., Maex, R., and De Schutter, E. (2000). Precise spike timing of tactile-evoked cerebellar Golgi cell responses: a reflection of combined mossy fiber and parallel fiber activation? Prog. Brain Res. 124, 95-106.

Watanabe, D., Inokawa, H., Hashimoto, K., Suzuki, N., Kano, M., Shigemoto, R., Hirano, T., Toyama, K., Kaneko, S., Yokoi, M., Moriyoshi, K., Suzuki, M., Kobayashi, K., Nagatsu, T., Kreitman, R. J., Pastan, I., and Nakanishi, S. (1998). Ablation of cerebellar Golgi cells disrupts synaptic integration involving GABA inhibition and NMDA receptor activation in motor coordination. Cell 95, 17-27.

Watanabe, D., and Nakanishi, S. (2003). mGluR2 postsynaptically senses granule cell inputs at Golgi cell synapses. Neuron 39, 821-829.

Yamazaki, T., and Tanaka, S. (2007). Spiking network model for passage-of-time representation in the cerebellum. Eur. J. Neurosci. 26, 2279-2292.

Yarom, Y., and Cohen, D. (2002). The olivocerebellar system as a generator of temporal patterns. Ann. N. Y. Acad. Sci. 978, 122-134.

Received: 11 April 2008; accepted: 12 June 2008.

Citation: Front. Neurosci. (2008) 2, 1: 35-46. doi: 10.3389/neuro.01.008.2008

Copyright (c) 2008 D'Angelo. This is an open-access article subject to an exclusive license agreement between the authors and the Frontiers Research Foundation, which permits unrestricted use, distribution, and reproduction in any medium, provided the original authors and source are credited. 